\title{
Analysis of Genetic Diversity Using Simple Sequence Repeat (SSR) Markers and Growth Regulator Response in Biofield Treated Cotton (Gossypium hirsutum L.)
}

\author{
Mahendra Kumar Trivedi ${ }^{1}$, Alice Branton ${ }^{1}$, Dahryn Trivedi ${ }^{1}$, Gopal Nayak $^{1}$, Mayank Gangwar ${ }^{2}$, \\ Snehasis Jana ${ }^{2, *}$ \\ ${ }^{1}$ Trivedi Global Inc., Henderson, NV, USA \\ ${ }^{2}$ Trivedi Science Research Laboratory Pvt. Ltd., Bhopal, Madhya Pradesh, India
}

Email address:

publication@trivedisrl.com (S. Jana)

\section{To cite this article:}

Mahendra Kumar Trivedi, Alice Branton, Dahryn Trivedi, Gopal Nayak, Mayank Gangwar, Snehasis Jana. Analysis of Genetic Diversity Using Simple Sequence Repeat (SSR) Markers and Growth Regulator Response in Biofield Treated Cotton (Gossypium hirsutum L.). American Journal of Agriculture and Forestry. Vol. 3, No. 5, 2015, pp. 216-221. doi: 10.11648/j.ajaf.20150305.17

\begin{abstract}
Cotton is the most important crop for the production of fiber that plays a key role in economic and social affairs. The aim of the study was to evaluate the impact of biofield energy treatment on cotton seeds regarding its growth, germination of seedling, glutathione (GSH) concentration, indole acetic acid (IAA) content and DNA fingerprinting using simple sequence repeat (SSR) markers for polymorphism analysis. The seeds of cotton cv. Stoneville-2 (Gossypium hirsutum L.) was obtained from DNA Land Marks Inc., Canada and divided into two groups. One group was remained as untreated, while the other was subjected to Mr. Trivedi biofield energy and referred as treated sample. The growth-germination of cotton seedling data showed higher germination (82\%) in biofield treated seeds as compared to the control (68\%). The alterations in length of shoot and root of cotton seedling was reported in the treated sample with respect to untreated seeds. However, the endogenous level of GSH in the leaves of treated cotton was increased by $27.68 \%$ as compared to the untreated sample, which may suggest an improved immunity of cotton plant. Further, the plant growth regulatory constituent i.e. IAA concentration was increased by $7.39 \%$, as compared with the control. Besides, the DNA fingerprinting data, showed polymorphism (4\%) between treated and untreated samples of cotton. The overall results suggest that the biofield energy treatment on cotton seeds, results in improved overall growth of plant, increase germination rate, GSH and IAA concentration were increased. The study assumed that biofield energy treatment on cotton seeds would be more useful for the production of cotton fiber.
\end{abstract}

Keywords: Biofield Energy, DNA Fingerprinting, Polymorphism, Cotton cv. Stoneville-2, Glutathione

\section{Introduction}

The cotton genus has more than 50 species reported worldwide in arid, semi-arid regions. It is indigenous to the tropic and subtropics regions [1]. Cotton is regarded as a vital source of seed oil and protein meal and is the major cash crop in the World. Cotton (Gossypium spp.), belongs to family Malvaceae, and is among the most important non-food crops, which occupies a significant position from both agricultural and manufacturing sectors points of view. It is the major source of one of the basic human need i.e. clothing apart from the other fiber sources viz. jute, silk and synthetics. Hence, it is one among the most cultivated and traded commodities in the World. Countries such as USA, China, Sudan, Egypt, Australia and
India are the major producers of cotton. Cotton industry throughout the world has wide economic market of about $\$ 500$ billion per year [2]. Apart from its economic importance, cotton has been regarded as the standard experimental model system to study polyploidization, cell elongation, cellulose, and cell wall biosynthesis [3, 4]. However, it is the only common plant, which yields single-celled fibers [3].

To promote the growth, development, and yield of agricultural crops, plant hormones plays a major role [5]. Indole-3-acetic acid (an auxin), is an endogenous phytohormone, mainly produced in the meristemic tissues of root apices, stem, and young developing leaves [6], and plays an important role in growth and development of root [7]. Multiple roles of glutathione in plant metabolism have been reported such as signaling of sulfur status, heavy metal 
tolerance, pathogen response, resistance to xenobiotics, and antioxidative defense and redox control [8]. The level of growth hormones, seed variety, use of pesticides, environmental factors, etc. plays a major role in final yield of the cotton. Recent reports from textile industry states the deficiencies in the quality of cotton, which include poor seed inputs, poor fiber attributes, rapid deterioration of fiber quality, wide range of contaminants, poor soil and rain-fed situations, etc. These all factors contributes to poor yield and increases the cost of cultivation [9]. Despite of several advances in agricultural sciences, some safe and natural approach is still required to improve the agricultural crops yield. In search of some cost effective and safe approach, authors studied the impact of biofield energy treatment on cotton seeds in terms of overall growth and yield of cotton.

Biofield energy, the electromagnetic field/energy that permeates and surrounds the living organisms is reported to have the capacity to improve the germination rate, enhance the biochemical markers and improved other agrochemical parameters $[10,11]$. However, the energy can exists in various form such as kinetic, potential, electrical, magnetic, and nuclear, and human nervous system consist of chemical information in the form of electromagnetic signals. Biofield involves regulation of electromagnetic information, which regulating hemodynamics. Energy medicine is one of the complementary and alternate medicine (CAM). According to National Health Interview Survey (NHIS), conducted by the Centers for Disease Control and Prevention's (CDC) and National Center for Health Statistics (NCHS), energy therapy was reported to be very common among adults [12]. Biofield treatment on agricultural crops will be new and upcoming approach worldwide to improve the agricultural productivity. Mr. Mahendra Kumar Trivedi possesses unique biofield energy, which has been reported to alter the growth characteristics in the field of agricultural science research [13] and plant biotechnology [14]. Mr. Trivedi's unique biofield treatment is also termed as The Trivedi Effect ${ }^{\circledR}$.

After considering the significant outcomes of biofield energy treatment, the study was designed to evaluate the impact of The Trivedi Effect ${ }^{\circledR}$ on cotton with respect to growth, yield, and genetic variability parameters (DNA fingerprinting) using standard molecular method.

\section{Materials and Methods}

Cotton cv. Stoneville-2 (Gossypium hirsutum L.) was obtained from DNA LandMarks, Montreal, Canada. The seeds of cotton were divided into two parts, one part was considered as control, no treatment was given. The other part was coded as treated and subjected to Mr. Trivedi's biofield treatment. The DNA fingerprinting analysis was performed using SSR markers.

\subsection{Biofield Treatment Strategy}

The treated group sample of cotton seeds was subjected to Mr. Trivedi's biofield treatment under laboratory conditions. Mr. Trivedi provided the biofield treatment through his unique energy transmission process to the treated group without any touch for few minutes. The treated sample was assessed for growth germination of seedlings, glutathione (GSH) level and indole acetic acid (IAA) content in roots and shoots of cotton plant [15].

\subsection{Impact of Biofield Energy on Juvenile Growth of Cotton Plant}

Control and treated cotton seeds were soaked for 6 hours in distilled water. The water soaked seeds were wrapped with moist tissue paper and kept in dark condition for germination. Juvenile growth was measured by recording the percent of germinated seeds, time taken for emergence of both radicle and plumule, and the length of shoot and root of young seedlings [15].

\subsection{Estimation of Glutathione in Cotton Leaves}

For the extraction of GSH approximate $5 \mathrm{gm}$ of cotton leaves were crushed and mixed with $5 \mathrm{~mL}$ of $80 \%$ cold methanol (as a solvent). Further, the extract was sonicated for 10 minutes, and $1 \mathrm{~mL}$ of $5 \%$ tricholoroacetic acid (TCA) was added to the extract. This sample was used for the analysis of GSH content. The GSH levels were estimated as per Moron et al. and TCA was taken as blank [16].

\subsection{Estimation of Indole Acetic Acid (IAA) Content in Cotton Seedlings}

For the extraction of IAA approximate $200 \mathrm{mg}$ plant tissue was grinded with $5 \mathrm{~mL}$ of $80 \%$ chilled methanol. The extract was filtered through Whatmann filter paper (No. 1). After filtration the final volume of extract was made up to $10 \mathrm{~mL}$ using $80 \%$ ice-cold methanol. Then optical density was measured after 30 minutes at $530 \mathrm{~nm}$ using ultra-violet visible spectrophotometer. IAA was analyzed using Tang and Bonner's method. Freshly prepared Salkowski's reagent was used for the detection of IAA content in cotton seedlings [17].

\subsection{DNA Fingerprinting}

\subsubsection{Plant Material and Primers}

Two series of seed aliquots (series A and B) were prepared for cotton cv. Stoneville-2. The seeds of the untreated sample (series "B") and seeds on the treated sample (series "A") were sowed. When plants reached the appropriate stage, leaf discs were harvested from each plant. DNA extraction was performed according to DNA LandMarks standard protocols. Purified DNA was then diluted to a concentration of approximately $25 \mathrm{ng} / \mu \mathrm{L}$. The marker of cotton was selected for PCR reactions and were amplified following DNA LandMarks. These markers were based on probes selected from a cDNA library, as per standard protocol for simple sequence repeat (SSR) on cotton samples [18, 19].

\subsubsection{Data Collection and Scoring}

Detection of amplified fragments was performed on ABI 3700 DNA sequencer (Applied Biosystems ${ }^{\circledR}$, Massachusetts, USA) and integrated systems for sequencing. Fragment size was generated by GeneScan software (Applied Biosystems, 
Massachusetts, USA) based on an internal size standard (GS-500) loaded with each cotton sample. Relative size of each detected fragment was then binned into categories to associate an allele size to this specific fragment using Genotypes software (Applied Biosystems, Massachusetts, USA). Each bin was defined as being \pm 0.7 base pair apart from any given allele size for a specific marker. Any data falling outside this range was reanalyzed and binned manually or declared "failed" by the scorer.

\subsubsection{Level of Polymorphism and Similarity Analysis}

The level of polymorphism was evaluated by calculating the ratio between the numbers of markers giving a true allelic variation type polymorphism by the total number of markers amplifying on the samples. Class 2 markers were removed from the calculation because of the uncertainty that such polymorphism can represent. The fingerprint of each sample was compared by similarity analysis using software "NTSYSpc V2.10" (NTSYS-PC 2.10, Applied Biostatistics, Setauket, NY, USA) with the Jaccard coefficient. A similarity coefficient of 1 indicates identity of the sample. The smaller the coefficient, the more diverse are the lines [20].

\subsection{Statistical Analysis}

Data from growth germination of seedling and indole acetic acid (IAA) were expressed as mean \pm S.E.M. between control and treated cotton seeds at the end of the experiment.

\section{Results and Discussion}

\subsection{Effect of Biofield on the Growth of Young Cotton Seedlings}

Plant population, growth, and canopy of cotton plant are the major yield contributing parameters, that overall contributes the final yield of cotton crop. Proper irrigation system and the management of various physical parameters plays a vital role in final yield of cotton. To increase the yield of crop, use of sophisticated equipment for crop growth, use of chemicals, pesticides, etc. were practiced. All these methods have their own merits or limitations. Growth of plant seedlings are also depends on spacing between the newly grown crops, which results in growth modifications that affect the final yield [21]. The plant height and number of monopodial branches per plant are some of the important vegetative factor which will effect and direct the cotton yield. The number of nodes and sympodia of cotton plant was also direct with plant height [22]. The rate of germination of cotton seedling data, and length of control and treated samples are shown in Table 1. It was observed that biofield energy treatment on cotton seeds results in improved percentage of germination, and length of the plant root and shoot. Based on the results, the control seeds of cotton showed $68 \%$ germination, while the biofield treated seeds showed $82 \%$ germination. Some seeds of control group failed to germinate as compared with the treated seeds, might be due to less supply of oxygen, which causes metabolic abnormalities. Contrarily, biofield treatment might provide the sufficient energy to the seeds through biofield energy, which resist the oxygen deficit conditions and results in improved germination rate. Biofield treated cotton seeds resulted in better germination, without any associated infections in leaves and steam, and improved plant height (Figure 1). After germination, plants shoot and roots were measured, which showed slight improved length of shoot, while decreased length of roots as compared with the control group. However, various environmental factors such as light, temperature, oxygen, etc. play an important role for final yield as they affects the seed germination to emergence during the first 10 days [23]. Biofield treatment, could be a new and alternative approach to improve the overall growth, and yield of cotton crops.

Table 1. Effect of biofield energy treatment on growth-germination rate of cotton seedlings on 10 day old plant.

\begin{tabular}{llll}
\hline \multirow{2}{*}{ Group } & \multirow{2}{*}{ Germination (\%) } & \multicolumn{2}{l}{ Length $(\mathrm{cm})$ Mean \pm S.E.M. } \\
\cline { 3 - 4 } & & Shoot & Root \\
\hline Control & 68 & $7.59 \pm 0.014$ & $6.80 \pm 0.060$ \\
Treated & 82 & $7.60 \pm 0.020$ & $5.78 \pm 0.047$ \\
\hline
\end{tabular}

$\mathrm{n}=50$; S.E.M.: Standard error of mean

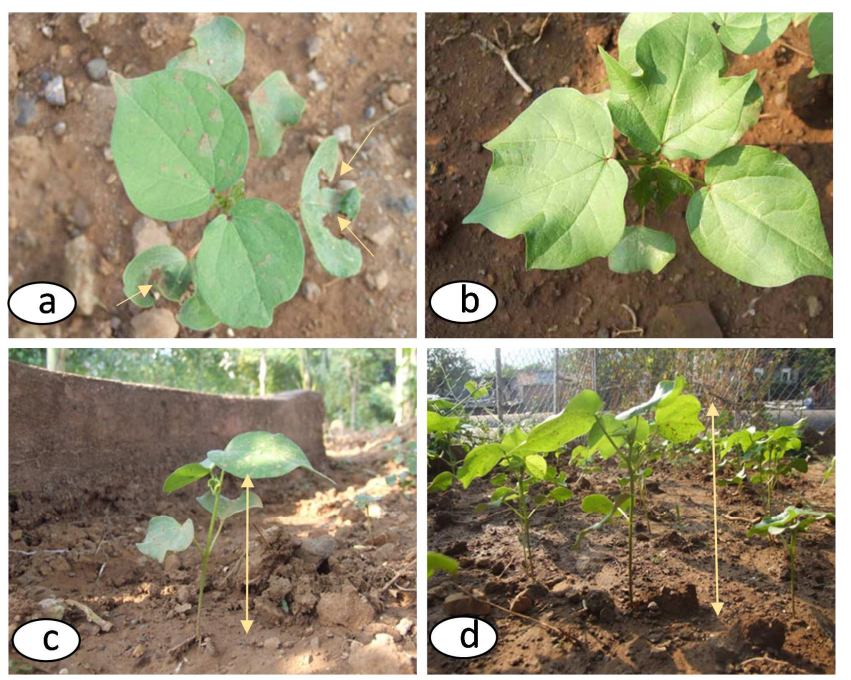

Figure 1. Effect of biofield energy treatment on cotton plant (a) control cotton crops marked with high infection in most of the leaves (b) biofield treatment showed leaves were bright green and glossy, with more pods per plant and free from any kind of disease or pest attack, (c) control cotton plant showed less plant height and with slow growth, (d) biofield treated cotton showed plants with more length as compared with control with more secondary and tertiary branches.

\subsection{Estimation of Glutathione Level in Cotton Leaves}

$\mathrm{GSH}$ is one of the important chemical entities in plants involved in the detoxification of reactive oxygen species (ROS). Studied in support of the role of GSH in oxidative stress have been reported. Stress can be induced due to exposure to chemical oxidants [24], gaseous pollutants [25], high air temperatures, and water stress [26]. Effect of Mr. Trivedi's biofield energy treatment on cotton seeds showed 
$0.176 \mathrm{mM}$ GSH concentration in control group, while 0.225 $\mathrm{mM}$ in treated group. Overall, 27.68\% increased level of GSH was reported after biofield treatment as compared with the control (Table 2). The plant glutathione system is regarded as the best stress marker in plant ecophysiology in drought tolerance conditions, by maintaining its redox status [27]. It is related to the sequestration of xenobiotics and heavy metals, while is an essential component of the cellular anti-oxidative defense system, which will regulate and control the ROS [28]. As redox reaction and antioxidantive defense plays a central role, it made glutathione system as stress marker in the plants.

During infection by fungal pathogens, plant cells respond by expressing a battery of disease response genes, which can result in the production of various toxic plant products, including active oxygen species and phytoalexins. In addition, an invading fungus or microbe, may produce stress-inducing chemicals, such as phytotoxins, resulting in significant stress and damage to the host cells. One main noticeable response of plants are the increased expression of glutathione S-transferase (GST) genes following infection by pathogens [29]. In the present work glutathione level in plant cell, as a biochemical marker for immunity was increased, that might be due to increased immunity after biofield treatment. Biofield energy might redefines the ionic strength and may provide better conditions for reactive oxygen species to occur, which results in changed GSH concentration. Our experimental results, conclude that biofield energy treated cotton seeds might resist in severe drought conditions, or different unfavorable environmental conditions, and grown with high GSH level as compared with control untreated seeds of cotton, which results in final yield of cotton fibers.

Table 2. Effect of biofield energy on endogenous level of glutathione in leaves of cotton.

\begin{tabular}{lllllll}
\hline Group & a & b & c & d & $\begin{array}{l}\text { Mean } \pm \\
\text { S.E.M. }\end{array}$ & $\begin{array}{l}\% \\
\text { change }\end{array}$ \\
\hline Control & 0.161 & 0.162 & 0.185 & 0.198 & $0.177 \pm 0.009$ & 27.68 \\
Treated & 0.200 & 0.202 & 0.202 & 0.298 & $0.225 \pm 0.024$ & \\
\hline
\end{tabular}

$\mathrm{a}, \mathrm{b}, \mathrm{c}$, and d are four studied replicas; S.E.M.: Standard error of mean; Values are presented as millimolar $(\mathrm{mM})$

\subsection{Estimation of Indole Acetic Acid (IAA) Content in Cotton Seedlings}

IAA is the most common phytohormone and, physiologically active auxins. It is produced in cells of the apex and very young leaves of the plant via. several independent biosynthetic pathways, and also produced by plant-associated commensal bacteria. The concentration of auxin can also be depends upon the level of plant infections [30]. However, IAA was reported with production of longer roots and enhanced root hairs by increasing the nutrient uptake from soil [31]. Further, IAA stimulates cell elongation by altering the necessary conditions such as increase in permeability of water and osmotic contents into cell, increase the cell wall synthesis via protein synthesis, and decrease the wall pressure. It also delays or inhibits the leave abscission, and induces flowering and fruiting. The difference in IAA concentrations in cotton seedlings before and after biofield treatment was presented in Figure 2. Control group showed IAA levels as $6.36 \mu \mathrm{g} / \mathrm{mL}$, while after biofield treatment, it showed increased level as $6.83 \mu \mathrm{g} / \mathrm{mL}$. The IAA concentration was calculated using rapid, determination using colorimetric principle by Salkowski test $[32,33]$. However, the IAA concentration was increased by $7.39 \%$, which could be related with the improved overall growth of the plant, which leads to increase the final yield of crop. It can be assumed, that biofield treatment on cotton seeds, might enhance the biosynthetic pathways of IAA synthesis, or may inhibit the growth of phytopathogens, which results in increased level of IAA in biofield treated group.

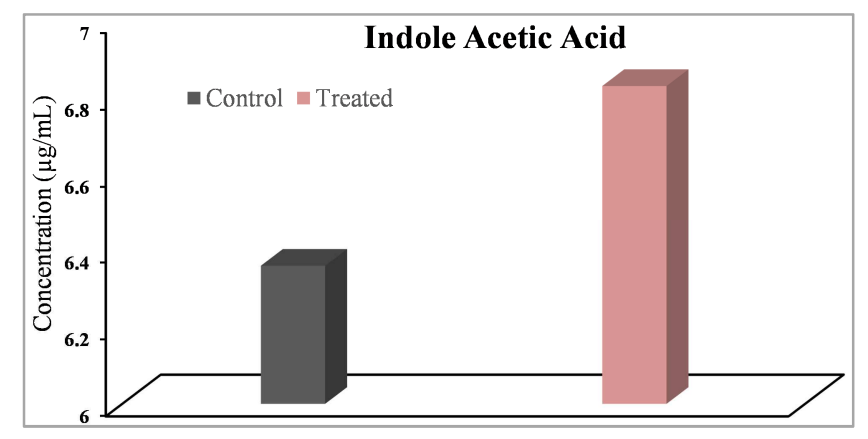

Figure 2. Concentration of indole acetic acid (IAA) in cotton (Gossypium hirsutum L.).

\subsection{DNA Fingerprinting}

Ninety-nine markers out of the 100 simple sequence repeat (SSR) markers were screened on the 2 samples of cotton amplified bands of the expected molecular weight. Ninety-four markers were categorized as "monomorphic", while five showed polymorphism between the treated and untreated lines. The polymorphism detected with these five markers could be classified into two categories. One was true allelic variation, while the other was additional band or a shift in molecular weight. One of the tested marker (JESPR-206) had not amplify in any fragment. The level of true polymorphism between the treated and untreated samples was evaluated at $4.0 \%$ (4/99). Overall, results suggest that biofield treatment resulted in polymorphism in biofield treated cotton seeds as compared with the control, which suggest that biofield energy might act and alter the genetic relatedness of cotton species.

Several studies suggest that the polymorphic DNA is responsible to give information about the ideal genetic markers, due to its selectively neutral nucleotide sequence and distinct genomes pattern [34]. Microsatellite or SSR markers have emerged as the most versatile and popular genetic marker in the plant systems. Because of their co-dominant, multiallelic nature, and hyper-variability, they are the leading markers for fingerprinting, conservation genetics, plant breeding, and phylogenetic studies. Microsatellites are more variable and informative than 
Restriction Fragment Length Polymorphism (RFLP), Random Amplified Polymorphic DNA (RAPD) and Amplified Fragment Length Polymorphisms (AFLPs) [35].

Plants are reported with high level of plasticity, as compared with animals, which suggest better adaptive capability in their DNA due to the environmental responses. The changes are visible and can be reflected in various morphological characteristics, such as better canopy, length of root and shoot, etc. along with genetic alterations. Biofield treatment on agricultural crops such as Withania somnifera, Amaranthus dubius, tomato, etc. were recently reported as an alternate method to improve the growth of crop, with improved overall agronomical characteristics (i.e. leaf, stem, flower, seed setting, immunity parameters, chlorophyll content, etc.) [14,15]. Our experimental results are supporting with the studies on in vitro growth germination of seeds, plant growth, and development using magnetic or electromagnetic fields [36,37]. According to Rakosy-Tican et al. magnetic field influence the growth of potato and wild Solanum species. They have reported significant stimulation of leaf growth, even at biochemical level, the quantity of chlorophyll $\mathrm{a}$ and $\mathrm{b}$ and carotenoids were increased by more than two-fold [38]. Biofield treatment suggests the mechanism based on energy fields, through bioelectromagnetics and biophysical fields that plays a major role in cellular structure and function of the human body [39]. Thus, the human body emits the electromagnetic waves in the form of bio-photons and moving electrically charged particles. Similarly, biofield treatment on cotton seeds might enhance catalase activity as reported with improved GSH and IAA level, which may promotes the germination. Another hypothesis suggests that biofield energy can cause mitotic incoherence against standard cytogenetic benchmarks, or may have indirect effect on plant mitosis by altering the cytosol condition. Therefore, biofield energy treatment, which might be considered as low electromagnetic fields, can improve the germination rate, increased level of important phytohormones, and overall growth of cotton plant.

\section{Conclusions}

In conclusion, biofield energy treated cotton seeds resulted in enhanced germination rate by $20 \%$ as compared with the control. Further, the length of the shoot and root of cotton plant after biofield energy treatment was reported to be increased as compared with the control. Moreover, GSH level (i.e. a biochemical marker for immunity level) in plant cell of biofield treated cotton seeds was increased by $27.68 \%$, which suggest increased immunity of cotton plants after biofield treatment. The IAA concentration after biofield treatment was increased by $7.39 \%$, which may inhibit the growth of phytopathogens, and hence improved the overall growth of the plant. Polymorphism was detected between treated and untreated samples of cotton seeds. The percentage of polymorphism observed between treated and untreated samples was $4 \%$; which could be a notable data in support of biofield treatment on cotton. Based on study outcome, Mr. Trivedi's biofield energy could be used as better alternate approach to improve the overall yield of agricultural crops in near future.

\section{Abbreviations}
SSR: Simple sequence repeat;
IAA: Indole acetic acid;
ROS: Reactive oxygen species;
ASC-GSH: Ascorbate-glutathione;
PCR: Polymerase chain reaction;
NHIS: National Health Interview Survey;
NCHS: National Center for Health Statistics;
CDC: Centers for Disease Control and Prevention;
CAM: Complementary and Alternative Medicine.

\section{Acknowledgements}

Authors are thankful for DNA LandMarks Inc., Montreal, Canada for conduction SSR DNA fingerprinting assay of cotton, and thanks to Monad Nanotech Pvt. Ltd., Mumbai, India for their valued inputs for growth analysis and related parameters. Authors are grateful to Trivedi science, Trivedi testimonials and Trivedi master wellness for their support throughout the work.

\section{References}

[1] Abdellatif KF, Khidr YA, Mansy YM, Lawendey MM, Soliman YA (2012) Molecular diversity of Egyptian cotton (Gossypium barbadense L.) and its relation to varietal development. J Crop Sci Biotechnol 15: 93-99.

[2] Zhang T, Qian N, Zhu X, Chen H, Wang S, et al. (2013) Variations and transmission of QTL alleles for yield and fiber qualities in upland cotton cultivars developed in China. PLoS One 8: e57220.

[3] Kim HJ, Triplett BA (2001) Cotton fiber growth in planta and in vitro. Models for plant cell elongation and cell wall biogenesis. Plant Physiol 127: 1361-1366.

[4] Ruan YL, Llewellyn DJ, Furbank RT (2003) Suppression of sucrose synthase gene expression represses cotton fiber cell initiation, elongation, and seed development. Plant Cell 15: 952-964.

[5] Nickell LG (1982) Plant growth regulators: Agricultural uses, Springer, New York.

[6] Wareing PF, PhillipsI DJ (1970) The control of growth and differentiation in plants. Pergamon Press Ltd., New York, USA.

[7] Lopez-Bucio J, Hernandez-Abreu E, Sanchez-Calderon L, Nieto-Jacobo MF, Simpson J, et al. (2002). Phosphate availability alters architecture and causes changes in hormones sensitivity in the Arabidopsis root system. Plant Physiol 129: 244-256.

[8] Grill D, Tausz M, De Kok LJ (2001) Significance of glutathione in plant adaptation to the environment. Handbook of plant ecophysiology, Dordrecht: Kluwer. 
[9] http://www.indiantextilemagazine.in/uncategorized/factors-inf luencing-cotton-production/

[10] Sances F, Flora E, Patil S, Spence A, Shinde V (2013) Impact of biofield treatment on ginseng and organic blueberry yield. AGRIVITA J Agri Sci 35: 22-29.

[11] Lenssen AW (2013) Biofield and fungicide seed treatment influences on soybean productivity, seed quality and weed community. Agricultural Journal 8: 138-143.

[12] Barnes PM, Bloom B, Nahin RL (2008) Complementary and alternative medicine use among adults and children: United States, 2007. Natl Health Stat Report 10: 1-23.

[13] Shinde V, Sances F, Patil S, Spence A (2012) Impact of biofield treatment on growth and yield of lettuce and tomato. Aust J Basic Appl Sci 6: 100-105.

[14] Nayak G, Altekar N (2015) Effect of biofield treatment on plant growth and adaptation. J Environ Health Sci 1: 1-9.

[15] Patil SA, Nayak GB, Barve SS, Tembe RP, Khan RR (2012) Impact of biofield treatment on growth and anatomical characteristics of Pogostemon cablin (Benth.). Biotechnology 11: 154-162.

[16] Moron MS, Depierre JW, Mannervik B (1979) Levels of glutathione, glutathione reductase and glutathione S-transferase activities in rat lung and liver. Biochim Biophys Acta 582: 67-78.

[17] Tang YW, Bonner J (1947) The enzymatic inactivation of indoleacetic acid. I. Some charasteristics of the enzyme contained in pea seedlings. Arch Biochem 13: 11-25.

[18] Zhu LF, Zhang XL, Nie YC (2003) Analysis of genetic diversity in upland cotton (Gossypium hirsutum L.) cultivars from China and foreign countries by RAPDs and SSRs. J Agric Biotechnol 11: 450-455.

[19] Xiao J, Wu K, Fang DD, Stelly DM, Yu J, et al. (2009) New SSR Markers for Use in Cotton (Gossypium spp.) Improvement. J Cotton Sci 13: 75-157.

[20] Rohlf FJ (2000) NTSYSpc: Numerical Taxonomy System, Ver. 2.10q, Exeter, Setauket, NY, USA.

[21] Brar ZS, Singh N, Deal JS (2002) Influence of plant spacing and growth modification practices on yield and its attributing characters of two cotton cultivars (Gossipium hirsutum L.,). Journal of Research 39: 181-183.

[22] Graig WC, David B, Steve MB (2000) Analysis of cotton yield stability across population densities. Agron J 92: 128-135.

[23] Leonard OA, Pinckard JA (1946) Effect of various oxygen and carbon dioxide concentrations on cotton root development. Plant Physiol 21: 18-36.
[24] Iturbe-Ormaetxe I, Escuredo PR, Arrese-Igor C, Becana M (1998) Oxidative damage in pea plants exposed to water deficit or paraquat. Plant Physiol 116: 173-181.

[25] Grill D, Esterbauer H, Hellig K (1982) Further studies on the plants by catalase inhibitors. Plant Physiol 79: 1044-1047.

[26] Loggini B, Scartazza A, Brugnoli E, Navari-Izzo F (1999) Antioxidative defense system, pigment composition, and photosynthetic efficiency in two wheat cultivars subjected to drought. Plant Physiol 119: 1091-1100.

[27] Tausz M, Sircelj H, Grill D (2004) The glutathione system as a stress marker in plant ecophysiology: Is a stress-response concept valid? J Exp Bot 55: 1955-1962.

[28] Noctor G, Queval G, Mhamdi A, Chaouch S, Foyer CH (2011) Glutathione. Arabidopsis Book 9: e0142.

[29] Wagner U, Edwards R, Dixon DP, Mauch F (2002) Probing the diversity of the Arabidopsis glutathione S-transferase family. Plant Mol Biol 49: 515-532.

[30] Yamada $T$ (1993) The role of auxin in plant-disease development. Annu Rev Phytopathol 31: 253-273.

[31] Datta C, Basu P (2000) Indole acetic acid production by a Rhizobium species from root nodules of a leguminous shrub Cajanus cojan. Microbiol Res 155: 123-127.

[32] Gordon SA, Weber P (1951) Colorimetric estimation of indoleacetic acid. Plant Physiol 26: 192-195.

[33] Salkowski E (1885) Ueber das verhalten der skatolcarbonsa"ure im organismus. Z. Physiol Chem 9: 23-33.

[34] Bretting PK, Widrlechner MP (1995) Genetic markers and plant genetic resource management. John Wiley \& Son Inc. Canada.

[35] He GH, Meng RH, Newman M, Gao GQ, Pittman RN, et al. (2003) Microsatellites as DNA markers in cultivated peanut. BMC Plant Biol 3: 3-11.

[36] Hirota N, Nakagawa J, Koichi K (1999) Effects of a magnetic field on the germination of plants. J Appl Phys 85: 5717-5719.

[37] Yano A, Hidaka E, Fujiwara K, Iimoto M (2001) Induction of primary root curvature in radish seedlings in a static magnetic field. Bioelectromagnetics 22: 194-199.

[38] Rakosy-Tican L, Aurori CM, Morariu VV (2005) Influence of near null magnetic field on in vitro growth of potato and wild Solanum species. Bioelectromagnetics 26: 548-557.

[39] Schwartz GE, Simon WL, Carmona R (2007) The energy healing experiments: Science reveals our natural power to heal. (1stedn), Atria Books. 